\title{
URBANIZATION AND SUSTAINABLE FOOD PRODUCTION IN CHINA
}

\section{Li Guoqing}

Institute of Urban Development and Environmental Studies, Chinese Academy of Social Sciences

E-mail: ligq@cass.org.cn

Citation: Guoqing, Li, 2017. Urbanization and Sustainable Food Production in China. J. Asian Rur. Stud. 1(1): 53-59

\begin{abstract}
China is now facing urbanization and the migrants from rural area have increased significantly. The farmland was the core iuess of the new urbanization process. The contracted land management right, residence land use rights and collective construction land allocation right were the main contents of the property right of peasants. To establish a new mechanism to make peasants and the rural collective enjoy the reasonable land profit is important for the new round land reform in China. Based on that, this paper will explain how the rural land were transformed into urban poverty. This paper argued that replace rural retained land into urban property model was a new form of compensation for the rural land. By this model, the migrant farmers can obtain the compensation as the economic base in city and improve the willingness of farmers moving to city and transfer their land to enlarge average arable land scale to develop food production. The paper concluded that the way to solve the shortage of arable land was to speed up the process of urbanization, promote the circulation of cultivated land to realize the expansion of rural per capita arable land to ensure food security. Therefore, it is needed to build a unified construction land market, realize the same price and same right between state-owned land and rural collective land, giving farmers more property rights.
\end{abstract}

Keywords: Food self-sufficiency; Urbanization; Land survival right; Rural land; Urban property

\section{Introduction}

China now is facing the challenge to feed $19 \%$ of the world's population with only $7 \%$ of its farmland. The proportion of Chinese suffering from hunger and malnutrition has dropped from 21.4 percent in 1990 to 11.5 percent in 2012. China can achieve its long-held goal of $95 \%$ self-sufficiency in basic food stuffs by 2020 to meet its food security goals (State Council, 2008).

According to the official statistics of Chinese National Bureau (2014), the country's total grain output reached 601.935 million tons $(12,038.7$ billion kilograms) in 2013 , 
$2.1 \%$ higher than the previous year, marking the tenth year of consecutive growth starting from 2004, and China's grain output achieved "twelve even increase" in 2015.

During the January-to-December period in 2015, China's grain imports amounted to 125 million tons, increasing 24.2\% compared to the same period last year (Zhiyan, 2016). Some people worry that China has not enough food. In fact, the three major staple foods supply were even overflowing. Usually, if the grain stock ratio reaches $17 \%$ to $18 \%$ of the annual consumption, it can meet the requirement of food security. At present, China's three staple stock ratio reached 50\%, it was the highest stock consumption ratio in the world (Changhe, 2016).

Table 1. Total Grain Sown Area, Yield per Unit Area, and Total Grain

\begin{tabular}{lccc}
\hline & $\begin{array}{c}\text { Sown Areas } \\
(1000 \text { hectares })\end{array}$ & $\begin{array}{c}\text { Yield per Unit Area } \\
(\mathrm{kg} / \mathrm{ha})\end{array}$ & $\begin{array}{c}\text { Total Outputs } \\
(10,000 \text { tons })\end{array}$ \\
\hline Total Output of Grain & 113340.5 & 5482.9 & 62143.5 \\
Grouped by Seasons & & & \\
Summer Grains & 27692.3 & 5096.0 & 14112.0 \\
Early Rice & 5715.4 & 5894.8 & 3369.1 \\
Autumn Grains & 79932.8 & 5587.5 & 44662.4 \\
Grouped by Grain Varieties & & & \\
Grain & 95648.9 & 5982.9 & 57225.3 \\
Corn & 38116.6 & 5891.9 & 22458.0 \\
Rice & 30213.2 & 6892.5 & 20824.5 \\
Wheat & 30213.2 & 6892.5 & 20824.5 \\
Beans & 8851.6 & 1794.0 & 1588.0 \\
Tubers & 8840.0 & 3767.1 & 3330.1 \\
\hline
\end{tabular}

Note: Due to automatic round-off, the annual total was not equal to the total of all grain varieties. Grain mainly includes corn, rice, wheat, barley, sorghum, buckwheat, and oats.

Date source: National Bureau of Statistics of China, December 8, 2015.

The farmland was the core issue of the new urbanization process. The contracted land management right, residence land use rights and collective construction land allocation right were the main contents of the property right of peasants. To establish a new mechanism to make peasants and the rural collective enjoy the reasonable land profit was important for the new round land reform in China. The property compensation especially commercial service property can make the farmers enjoy the land value-added income for a long period and it will greatly improve the willingness to settle down in the city and it will improve Sustainable Food Production in China. Based on that, this paper will explain how the rural land were transformed into urban poverty. 


\section{Discussion}

\subsection{Problems of Agricultural Development in China}

China's agricultural development was facing two problems. One was the pressure on ecological environment. Under the situation of constant reducing of land resources, grain's "twelve even gross" depended on the fertilizer, pesticide and so on, which have caused the pollution of environment.

In 2013, China's heavily polluted arable land has reached about 50 million mu ( $1 \mathrm{mu}$ $=666$ square meter). Total farmland pollution exceeded the rate of $19.4 \%$, and mainly in minor contamination. Pollutants in farmland were mainly heavy metals and pesticides. Polluted farmland mainly located in southern China, where the agricultural areas were surrounded by industrial and mining areas, cities and suburbs. China's chemical fertilizer used per mu of arable land was about 3 times higher than that of the developed countries. The pesticide utilization rate was about 33\%, lower than in developed countries which as approximately $20-30 \%$, and contaminated 140 million mu arable land (Wangyu, 2013).

The other problem was land. Arable land demand was only $80 \%$ which just produced $90 \%$ of the domestic grain and cooking oil. Therefore China must utilize external resources to meet its need. Moreover, urbanization development reduces land resources cultivated. At present, China's per capita arable land area decreased to $1.38 \mathrm{mu}$ (about 0.1 hectare) and only $40 \%$ of the world average. China's per capita water resources was less than 1/4 of the world average (Yangjie, 2016). China was also one of the world's 13 most water-stressed countries.

By the end of 2013, China's central government has established a new national food security strategy based on domestic supply and moderate imports, aiming to ensure production capacity and speeding up the development of agricultural science and technology.

\subsection{China Society in Transition: "From rural land to urban property"}

China's society is now in a transitional phase. Land problem was the core problem in the process of new urbanization. The farmers have three rights over the rural land: contracting land management rights, residence land use rights, collective construction land income distribution right (The Central Committee of the Communist Party of China, 2013). The third right was the main content of the property rights of farmers. The establishment of a mechanism to enable the farmer and the rural collective enjoying reasonable land value-added income legally was an important criterion for the land reform.

The property compensation, especially commercial property can make farmers enjoyed value-added land income in the long-term. It will enhances the farmers' willingness to move to the city greatly and access land circulation to promote food production. 
Decision of the Third Plenary Session of the $18^{\text {th }}$ CPC Central Committee put forward the construction of urban and rural unified land market. It means the rural collective construction gained the right to have the same price with state-owned land, and give farmers more rights to enable farmers enjoying the achievement of the urbanization development. At present, China's industrialization and urbanization is still at the rapid development stage. It relies on land expansion and land capitalization. Imbalance between construction land supply and demand will be more prominent.

In China, the land ownershipwas divided into two types, the rural collective land and state-owned land (Han and Zhu, 2013). Land usage was different between different ownership, and the price of state-owned land was much higher than rural collective land (Zhao et al., 2013). It is necessary to transfer the rural collective land into state-owned land for urban construction as the way for suburb village farmers to enjoy the land rights and interests as well. But at present, monetary compensation for land requisition cannot present the property rights well, also cannot protect stable life of migrant workers after they transformed from farmer into urban dweller. Therefore it hinders the migrant's settlement willingness. It is necessary to put forward a new land acquisition compensation mechanism.

\subsection{Major problems of rural land acquisition}

For a long time, there were two main problems existing in the process of land expropriation in China's rural area. One was the land compensation and the standard of the rural collective construction land converted into the state-owned construction land (Zhao et al., 2013).

First, the land compensation standard was low. China's current compensation standard bases on the "income value" or the actual economic value, rather than the land of the "transaction value". After the rural collective land has been converted into construction land, land acquisition compensation and resettlement compensation fees were in accordance with the 6 times of last three years average annual output value, the maximum was not more than 15 times of the standard. Due to the low price of agricultural products, land compensation price was also low, 10 times lower than it's transaction value.

The low land compensation cannot maintain the farmers' resettlement fees in the city. They cannot purchase house, and cannot to restart micro and small businesses. The education level and working skills of farmers who lost their land was relatively low, and it was hard to adapt to the urban living environment. They were in an obvious disadvantaged position in the employment market, and have low willingness to settle down. A number of social survey indicated that the migrant workers' were extremely low their willingness to settle down and change into citizenship, accounting for only $20-30 \%$ (Wang and Lu, 2014). This situation was far of the government's goal to promote 100 million agricultural population transfers in the town. 
Under the current cash compensation system, the land-lost farmers can't enjoy the land value-added income. On the other hand, the local government and the real estate developers obtained the land value-added profits. Farmer's comparing benefit suffered significant damage through the land transaction. Injustice compensation became a mass event. $60 \%$ petitions related to the land disputes, accounting for $40 \%$ of the total social petitions (Liu, 2013).

Second, after the Third Plenary Session of the eighteenth CPC Central Committee, the comparative benefit of farmers and citizens has changed significantly. Transformation of the migrant workers into citizenship did not means the employment and social security could be guaranteed. At the same time, rural household registration value increase greatly, and farmers did not want to give up the rural homestead and contracting land, leading to the further decline willingness to settle in the city.

\subsection{The village retained collective land use conversion and utilization}

With the acceleration of urbanization process, more and more villages and their farmland were incorporated into the cities, and the land has changed from collective ownership to state-ownership. During the land requisition process, village retained some collective land, villagers homestead and farmer plots, these three types of land will remain the original collective ownership, called as "urban village".

According to the proportion of the actual land requisition, village can retain about $10-15 \%$ of actual land requisition arrangement, using for village's economic development (The people's Government of Guangdong Province, 2016). The retained land use right belongs to the village collective. At present, many villages retained land has not been developed well to generate economic benefits.

\subsection{Zhejiang and Sichuan province: The experience of "replace village retained land into urban property"}

"Replace rural retained land into urban property" is a new form of compensation for the rural land. The village collective transfers the collective land into service facilities to obtain property value-added capital, using the land assets to support the village and villager's long-term welfare. The village collective land replacement follows the 5 steps as below.

First, village collective economic organization is the decision-making body of land assets use, and villagers have the decision-making right on land use. Second, the local Land Planning Bureau inspects the village land transfer. The contents of the audit include checking the ownership of land. Third, the land planning bureau and the village committee sign the land transfer agreement, the compensation will be a part of the currency and most of commercial service property. Fourth, the land bureau branch organize the auction of state-owned construction land, to determine the cooperative developer. Fifth, the village committee receives a real property according to the land transfer agreement 
The significance of "urban property replace by rural land" model: (1) establish the "the land value of Subsistence right " model gives migrants the material foundation to rebuild life in the city. In Taiwan, the current "land expropriation ordinance" distinguishes the value between land property rights and the right to survival, focusing on protecting the expropriation farmer to obtain land again, to ensure migrant farmers become beneficiaries of urbanization. As long as the land owners depend on the expropriated land resources to survive, the land has the nature of survival right but not just the nature of property right. Government need to perform complete responsibility to make land owner to obtain another piece of land in the same region, in order to ensure the expropriation of property right and the right to live. Taiwan land acquisition and compensation principle is called "reacquisition land principles".

Referring to the value idea of Taiwan's land survival right, the value of the land should be defined as the value of the subsistence right, in order to ensure that migrant farmers can obtain the compensation for their economic survival in the city. Also it can improve the farmers' willingness to move to the city. (2) Appling to the urban village land development and the outskirts land requisition."Replace rural land by urban property" policy is applicable to the villages retained land development. The government make policies to help developers and villages to establish cooperative relations to develop the village retained land, the village obtain apart of real property as land compensation.

This model can be extended to suburbs land requisition. Land expropriation village doesn't reserve retained land, but cooperate with the developer to make the develop plan. The village transfers their retained land to obtain monetary compensation and a certain proportion commercial service facilities impacting the formation of integrated urban and rural land market.

\section{Conclusion}

To sum up, Chinese grain production made consecutive growth in the recent decade and achieved the staple food self-sufficiency. But meanwhile, China also paid a heavy price for environmental pollution caused by excessive use of chemical fertilizers. The main reason for this problem is that the per capita arable land in China has limited the increase of grain output. One way to solve the shortage of arable land is to speed up the process of urbanization, promote the circulation of cultivated land to realize the expansion of rural per capita arable land to ensure food security. Therefore, it is needed to build a unified construction land market, realize the same price and same right between state-owned land and rural collective land, giving farmers more property rights. The "replace village retained land into Urban property policy" is a effective way for improving the farmers willingness to settle in the city and convert to urban citizen. 


\section{References:}

Guoqing, Li., 2013. A New Road to Urbanization with Chinese Charac- teristics, Beijing: Social Sciences. Academic Press (China).

Guoqiang, Cheng. 2015. The real problem of food security in China,http: //opinion.caixin.com/2015-02-05/100781776.html,5th February,.

Guoqing, Li., 2011. The current situation of Chinese Society III, With Jun Oyane and Hirotoshi Shibata. Tokyo: Senshu University Press.

State Council, 2008, National medium and long term planning framework of food security, 2008-2020.

Zhiyan Consulting Group. 2016. China Grain Market Research and Industry Outlook Report in 2016-2022, Zhiyan Consulting Group Press.

Zhao, Changhe. 2013. Cause of High Inventory of Three Staple Grains in China, Agricultural Outlook, No.3.

Wangyu, Yuwenjing, 2013. China consumed about 30\% of world fertilizer. Xinhua net, March 17.

Yangjie, 2016. The total amount of water resources and per capita water resources ranking in some provinces of China. China Water Net, Aug, 19, 2016.

The Central Committee of the Communist Party of China, 2013. Communique of the Third Plenary Session of the 18th Central Committee of the CPC,Renmin Press.

Han Dejun and Zhu Daolin, 2013. Game-theory Analysis on the Evolution of Rural Land Institutions in China, China Land Sciences, No.7.

Zhao, Ziyan; Qiu, Daochi, Wang, Jing, and Cai, Jin. 2013. Study on the Progress of Evaluating Rural Land Assets, China Land Sciences, No.7.

Wang, Guangqi; Lu, Guixing. 2014. Study of the Migration Willingness and Directions of the Farmers under the Background of New Urbanization Contraction, Research of Institutional Economics, No.4.

Liu, Shouying, 2013. 60\% Group Petitions Related with the land, Xinhua Net, Oct 14.

The people's Government of Guangdong Province, 2016. The Rural Retained land Expropriation Management Measures in Guangdong Province, Gd.gov.cn net, April 28, 2016. 